\title{
What will it take to make a successful administrative professional in the fourth industrial revolution?
}

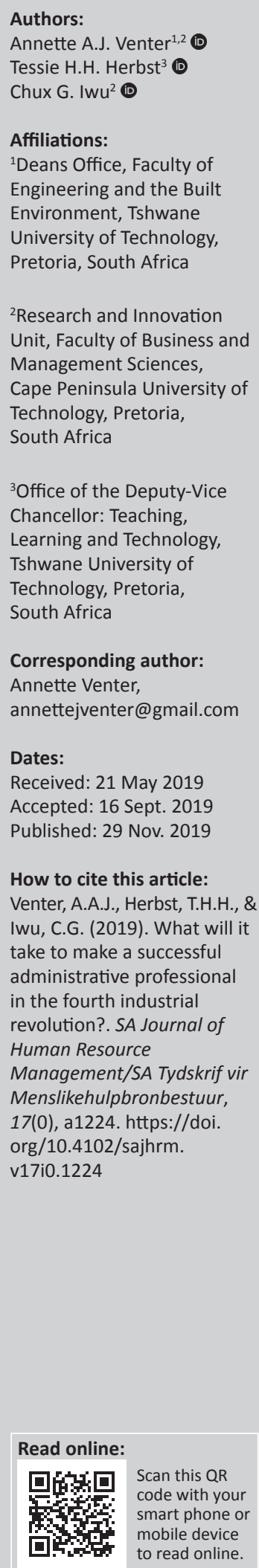

Orientation: The rapid economic developments of the last decade have been driven by the impact of revolutionary developments in information and communication technologies. These technological developments have irreversibly and significantly affected the role of an administrative professional with regard to assimilation, processing and utilisation of information.

Research purpose: This study investigates the impact of global and national key drivers of change and transformation on the skills requirements of administrative professionals with the aim of developing a future-focused success profile to enable them to be effective in the new world of work.

Motivation for the study: The study is motivated by the personal experience of one of the researchers, and her observation of the impact of technological advances and the necessity for administrative professionals to integrate new skills, knowledge and attitudes into the new world of work.

Research approach/design and method: This study followed a mixed methods approach, using both pragmatist and constructivist paradigms. The pragmatist approach provides meaning through the natural work environment of an administrative professional, whilst a constructivist approach is followed to compile a whole-brain success profile. From a sample of 354 , a total of 219 responses were received, which represent a response rate of $62 \%$. Data were collected through a visual analogue scale-type questionnaire.

Main findings: The findings reveal that the skill requirements for the future success of an administrative professional involve proficiency to function from all quadrants of the wholebrain model.

Practical/managerial implications: The curricula of undergraduate qualifications should be adapted to allow for shorter credit-bearing skill modules in line with the latest trends in technology, because the profession of administrative professionals is mainly skill-based. In addition, owing to the focus of the study on the new world of work, the findings could be related to most occupations.

Contribution or value-add: This study contributes to the construction of a future-focused whole-brain model, according to the functional skills, essential skills and emerging skills required for optimal effectiveness of administrative professionals in the future-focused world of work.

Keywords: functional; essential future skills; emerging future skills; administrative professionals; Fourth Industrial Revolution.

\section{Introduction}

The revolutionary developments in information and communication technologies have impact not only on administrative professional's work environment but also on their future roles and accompanying thinking processes. More importantly, the traditional skills of administrative professionals have become obsolete, with a shift towards executive support, which entails skills at a more advanced level.

Authors such as Domeyer (2005) and Rorbak (2012) confirm that the increasingly complex and specialised effects of rapid developments in information technology and its diversity in business environment pose a challenge to the existing work behaviours. This also requires that

Copyright: @ 2019. The Authors. Licensee: AOSIS. This work is licensed under the Creative Commons Attribution License. 
administrative professionals acquire more knowledge on a variety of subjects, and that they apply more skills than at any other point in the history of the profession. Technological changes have also had a significant impact on the role of administrative professionals with regard to the assimilation, processing and utilisation of information. A combination of technical expertise and desirable personal attributes contributes to the career success and effectiveness of administrative professionals. Several researchers (Ensminger, Surry, Porter, \& Wright, 2004; Hollis-Turner, 2008, p. ii) emphasise the importance of 'a perceived need to change old methods' and 'the need for developing psychological ownership and competencies by employees in order to successfully facilitate change within an organisation'.

The call to adapt to new ways of thinking in the new world of work led Venter (2011) to investigate the ideal profile of preferred thinking styles of a contemporary administrative professional. The results revealed that the current preferred thinking styles of administrative professionals might be inadequate for performing effectively in the newly developing world of work. The necessity for administrative professionals to develop from a predominantly left-brain thinking preference to become whole-brain thinkers, by incorporating right-brain thinking in executing their roles effectively, emerged from this study. The contemporary administrative professional would continue to need left-brain thinking skills to function effectively. However, based on Venter's findings, such thinking needs to be complemented by right-brain thinking in order for the administrative professional to function more effectively in the new world of work.

The whole-brain thinking equips a person to develop the skills to interpret managerial styles as well as resolve business problems pertaining to production, planning, communication, teamwork and reaching goals. Whole-brain thinking also provides an invaluable basis for understanding processes of thinking and the interrelation of knowledge, skills and competence (Herrmann \& Herrmann-Nehdi, 2015; Neethling \& Rutherford, 2005). Herrmann (1995) asserts that the:

$[C]$ ompetence to perform a given task comes through training and experience and can be developed to reasonable, even superior levels whether or not the person is attracted to that task. (p. 76)

Thinking that is associated with the whole-brain concept (Herrmann \& Herrmann-Nehdi, 2015) emerged in research conducted by the World Economic Forum (2016), which found that an immense disruption of skills arose from the onset of the Fourth Industrial Revolution (4IR).

This article is a response to Bussin and Brigman's (2019) statement that key demographic and economic drivers of change continuously change the context of employment, which will lead to a shortage of 60 million knowledge workers worldwide by 2020. In addition, this study is based on the recommendations of a previous study by Venter
(2011), who came to the conclusion that administrative professionals henceforth need to complement their predominantly left-brain thinking with right-brain thinking to function effectively in the new world of work. The significance of this study therefore lies in its attempt to determine the impact of global key drivers of change on the future-focused whole-brain success profile for optimal effectiveness of administrative professionals in the future world of work.

\section{Literature review}

The economic characteristics of the world have changed dramatically. Societies have evolved over four industrial revolutions from a group of farmers to consumers sharing their experiences in a knowledge-based society. To transition amongst economies requires a different way of thinking. Thinking associated with the left brain emerged during the agrarian economy, the industrial economy and the information age. The industrial economy fostered quality and productivity. Electronics, technological developments and global competition characterised the digital age. The ability to acquire and apply theoretical and analytical knowledge distinguished knowledge workers. The service economy emphasised proficiency, it increased productivity and strove for quality in goods and services (Bloem et al., 2014; Ferreira \& Teixeira, 2013; Herrmann, 1995; Hosany \& Witham, 2010; Howes, 2016; Kamel, Melo, De Souza, Lima, \& Lopes, 2008; OECD, 2000; Pine \& Gilmore, 1998, 2001; Pink, 2005; Pompidou, 2007; Rowson \& McGilchrist, 2013; Seltzer \& Bentley, 1999; UBS, 2016).

With the emergence of the experience economy, a diverse set of skills came to the fore, with new technologies that engaged customers with experiences that involve and create emotions and affective memories, where different dimensions of sensory, social and spiritual stimulants focus on providing customers with holistic and long-lasting personal experiences. The emotional response of the creators and the empathisers at the delivery of a service appeals to the limbic system, and consequently to the right brain, which controls the limbic system (Ferreira \& Teixeira, 2013; Herrmann, 1995; Hosany \& Witham, 2010; Kamel et al., 2008; Pine \& Gilmore, 1998).

In addition, the conceptual age required the mastering of a new set of skills, including empathy, creativity and storytelling, which reflect right-brain thinking. The emphasis on right-brain thinking continues with the economic realm of relationships. The rise of social media gave brands and consumers a variety of platforms for conversations and connections, thus a different means of communication and social skills (Huitt, 2007; Pink, 2005; Smith, n.d.; Stanfield \& O'Hare, 2013).

Thinking associated with whole-brain thinking emerged in research by the World Economic Forum (2016), which found that there is an immense disruption to skills, driven by extreme automation and connectivity through artificial 
intelligence that has set the stage for the sharing economy (4IR). This has implications for the skill set that includes social and cognitive abilities as well as technical skills, resource management, processing (e.g. active listening, critical thinking and monitoring self and others), content skills (e.g. active learning, oral expression, reading comprehension, written expression, information, communication and technology literacy), system skills (such as judgement and decisionmaking and system analysis) and complex problem-solving abilities. In addition, for the workforce to be successful, it needs to go beyond these skills, namely to be flexible and to be able to adapt to change (Anderson \& Rainie, 2012; Bloem et al., 2014; Herrmann \& Herrmann-Nehdi, 2015; Quilligan, 2015; UBS, 2016).

The focus of the study is on the impact of global key drivers of change in the South African context and the impact thereof on administrative professionals. As stated by the UBS (2016), these global key drivers of change would have a negative impact on highly repetitive low-skill and medium-skill occupations.

Although South Africa is a young participant in these global trends, the key drivers of change have a significant impact on the current political and economic dialogue. Recognising the impact of changing economic structures on the future would continue to expand the ability of South Africa to grow globally by placing a competitive impetus on all South Africans (Cilliers, Hughes, \& Moyer, 2011; Fear, Botha, Young, Rautenbach, \& Groenewald, 2009; Silke, 2011). The Department of Higher Education and Training (2016) has compiled the National Skills Development Strategy (NSDS III) Progress Report 2011-2016 to serve as a key driving force in improving the effectiveness and efficiency of the skills development system. It also promotes partnerships between employers and public education institutions (including technical and vocational education and training colleges, universities, universities of technology, private training providers and sector education and training authorities) (Department of Higher Education and Training, 2016; Skills Development Facilitator Guide, 2013). In keeping with the need to recognise the impact of key drivers of change, the African Union points out on their website (https://www. un.org/en/africa/osaa/pdf/au/agenda2063.pdf) that the African Agenda 2063 serves as a masterplan for transforming Africa into a global powerhouse of the future. Of specific relevance is the aim to '[c]atalyse education and skills revolution and actively promote science, technology, research and innovation, to build knowledge, human capital, capabilities and skills to drive innovations [...] for the African century' (African Union Commission, 2015).

The characteristics of the new world of work, known as the 'key drivers of change' served as a guide to test the impact of global and national key drivers of change and transformation on the application of new knowledge and skills of administrative professionals in a South African context. The guide, as illustrated in Figure 1, is adopted from Burton and
Shelton (2010), Davies, Fiddler and Gorbis (2011) and the World Economic Forum (2016) to constitute a framework of emerging key drivers of change that transform global society and marketplace.

The increasingly complex and specialised effects of the explosion of information technology and its diversity in the business environment not only challenge existing work behaviours but also require administrative professionals to acquire more knowledge on a variety of subjects, and apply more skills, than at any other point in the history of the profession. They have also impacted significantly the role of administrative professionals with regard to the assimilation, processing and utilisation of information. A combination of technical expertise and desirable personal attributes contributes to the career success and effectiveness of administrative professionals. To successfully change within an organisation, employees should develop psychological ownership and new competencies (Domeyer, 2005; Ensminger et al., 2004; Hollis-Turner, 2008; Rorbak, 2012). Other factors that impact the effectiveness of administrative professionals were revealed in studies conducted by Ferreira and Van Antwerpen (2011) and Van Antwerpen and Ferreira (2016) amongst administrative support staff in the South African public service. The factors that are relevant to the subject are, amongst others, promises that are not kept with regard to skills improvement, such as attending training courses, ignorance regarding inclusion of centralised decision-making, and faster and more powerful computer hardware.

The results of Venter's (2011) investigation into the ideal thinking style preference profile of administrative professionals revealed that the preferred thinking styles of administrative professionals might be inadequate for performing effectively in the newly developing world of work. What also emerged is the necessity for them to develop from a predominantly left-brain thinking preference to become whole-brain thinkers by incorporating right-brain thinking in executing their roles effectively. According to Herrmann (1995), left-brain thinking relates to hard thinking processing, such as to organise information logically, analyse problems and solutions, rational, criteria and logical reasoning, quantitative issues and activities. Thus, left-brain thinking needs to be complemented by nonlinear and nonverbal right-brain thinking such as visual, conceptual, imaginative, spatial and simultaneous processes for administrative professionals to function more effectively in the new world of work.

Whole-brain thinking equips a person to develop the skills to interpret managerial styles as well as to resolve business problems pertaining to production, planning, communication, teamwork and reaching goals. It also provides an invaluable basis for understanding processes of thinking, and the interrelation of knowledge, skills and competence (Herrmann \& Herrmann-Nehdi, 2015; Neethling \& Rutherford, 2005). 


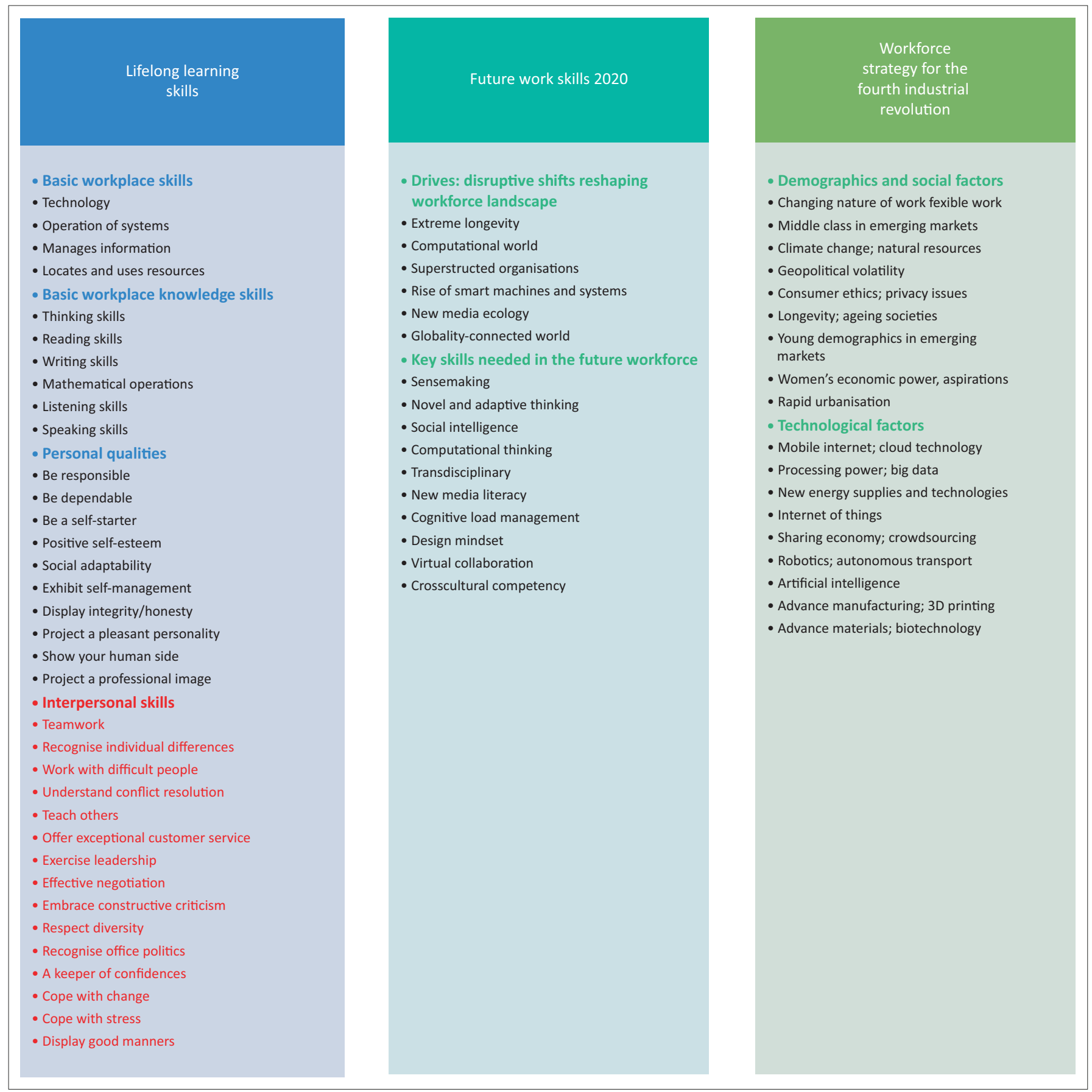

Source: Adapted from Burton and Shelton, 2010, pp. 41-70; Davies et al., 2011, p. 13; World Economic Forum, 2016, pp. 6-7 FIGURE 1: A guide for the key drivers of change.

The brain constantly changes when it learns a new skill set, for example a technical or a financial skill. Once the process of thinking is understood and utilised to support and enhance the effectiveness of employees, problem-solving, innovation, communication and achieving individual and company goals are promoted. Professionals are able to adapt to the continuous pace and the extent of change more effectively, and they could access different thinking styles that could provide appropriate responses to changing situations. Although individuals choose to solve problems in their preferred thinking style, access to all thinking styles is necessary to solve more complex problems. Individuals can adopt different thinking styles according to different tasks and situations. Whole-brain thinking encourages a person to complement less preferred thinking style preferences instead of disregarding the lack of necessary skills, which may cause anxiety and stress. Furthermore, the new world of work encourages a shift within educational institutions and the workforce. The historically separate worlds of work and learning originally focused on predominantly left-brain thinking and teaching. This was evident in the service economy, where knowledge workers excelled in left-brain thinking and were distinguished for 'their ability to acquire and apply theoretical and analytical 
knowledge' (Pink, p.16) (De Boer \& Van den Berg, 2001; Harypursat, 2005; Herrmann, 2005; Jensen, 2007; Kruger, 2008; Neethling \& Rutherford, 2005; Samuel \& Kohun, 2010; Sternberg, 1994; Van Niekerk, 2007).

\section{Theoretical framework}

Considering that the purpose of this study was to discover and interpret the impact of global key drivers of change on administrative professionals for effective performance in the changing world of work from a whole-brain perspective, the relevant key whole-brain human information processing theories were considered. These theories include Herrmann's Whole Brain ${ }^{\circledR}$ model (Herrmann, 1996; Herrmann \& Herrmann-Nehdi, 2015), Taggart's whole-brain human information processing theory (Taggart, 1980; Taggart \& Valenzi, 1990; Taggart, Valenzi, Zalka, \& Lowe, 1997), Sternberg's theory of thinking styles (Sternberg, 1990, 1994) and Kirton's model of cognitive style (Cassidy, 2004; Coffield, Moseley, Hall, \& Ecclestone, 2004; Kumar, 2014; Stum, 2009). Consequently, Herrmann's Whole Brain ${ }^{\circledR}$ theory has been chosen, given that the characteristics of the theory mainly encourage whole-brain development. Herrmann's Whole Brain $^{\circledR}$ theory thus serves as a conceptual framework for this study with the aim of constructing a future-focused wholebrain success profile.

In addition, Herrmann's Whole Brain ${ }^{\circledR}$ theory is chosen as Herrmann is acknowledged as the father of brain dominance technology in literature (De Boer, Du Toit, \& Bothma, 2015). Furthermore, his research provides a valid approach towards a theory for understanding how the brain processes information. He illustrates this through the four-quadrant model, which presents four modes of thinking and learning, not only two hemispheres, and is based on the Whole Brain ${ }^{\circledR}$ theory comprising the following key concepts (AlGhraibeh, 2015; Herrmann, 1996):

- Thinking styles are featured as neither good or bad, right or wrong.

- The thinking style shows a preference for mental activity that is quite different from the efficiency of performing that activity.

- Thinking styles tend to be constant over time.

Application of the model can harness cognitive diversity, such as improving the efficiency of teams and individuals, and for better problem-solving, decision-making, communication and management. The model is holistic and has factorial and construct validity when applied in the fields of business and education. Moreover, the Whole Brain ${ }^{\circledR}$ theory promotes professional development by encouraging the development of less preferred thinking styles. Consequently, Herrmann believes that thinking style flexibility supports responses to meet particular situational demands. Herrmann's Whole Brain ${ }^{\circledR}$ model and the Herrmann Brain Dominance Instrument (HBDI) represent one of the six recommended models in education and training. Furthermore, Herrmann's whole-brain approach provides evidence that using multiple thinking styles promotes development of students' full potential and deeper learning (Coffield et al., 2004; Herrmann, 1995; Herrmann \& Herrmann-Nehdi, 2015; Martins, 2015).

The triune brain theory and the left-brain/right-brain theory facilitated the development of Herrmann's Whole Brain ${ }^{\circledR}$ model. Popularisation of this theory was formed by clinical evidence provided by Robert Ornstein, Roger Sperry, Joseph Bogen and Michael Gazzanaga. These two hemispheres communicate with each other by means of connectors called the corpus callosum, the hippocampal commissure and the anterior commissure. Herrmann combined the elements of MacLean's triune brain model and Sperry's theories into a four-part model representing the Whole Brain ${ }^{\circledR}$ model (Herrmann, 1996, p. 15). The four-quadrant model therefore serves as an organising principle of how the brain works, namely that the four thinking styles metaphorically represent the two halves of the cerebral cortex (Sperry) and the two halves of the limbic system (MacLean). As illustrated in Figure 2, the cerebral mode represents the cognitive modes associated with the cortex, demonstrating Quadrants A and D of Herrmann's Whole Brain ${ }^{\circledR}$ model. Quadrants B and C represent the more visceral and emotional modes associated with the limbic system (Herrmann, 1996).

The above explanation of the Whole Brain ${ }^{\circledR}$ theory serves to interpret the results of the study and to construct a futurefocused whole-brain model. The Herrmann Whole Brain ${ }^{\circledR}$ model also forms the core of a future-focused whole-brain model, as illustrated in Figure 3.

Rapid economic developments of the past decade have had an irreversible impact on the set of skills and thinking

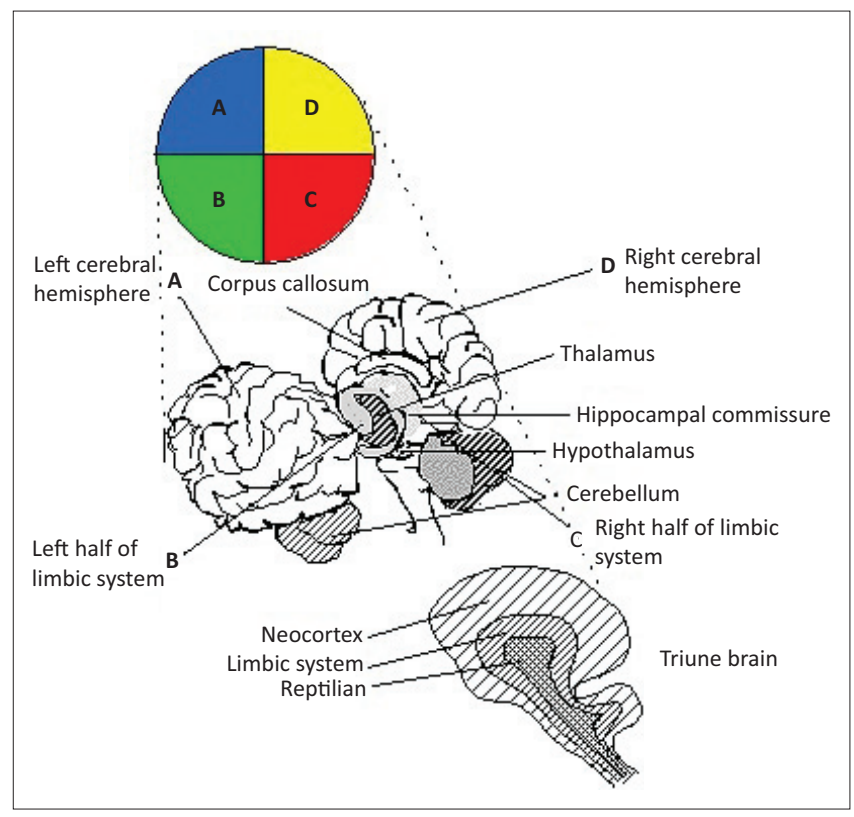

Source: Adapted from Herrmann, N. (1996). The whole brain business book. New York: McGraw-Hill.

FIGURE 2: The triune brain theory combined with the left-brain/right-brain theory which emerged into the four-quadrant concept. 


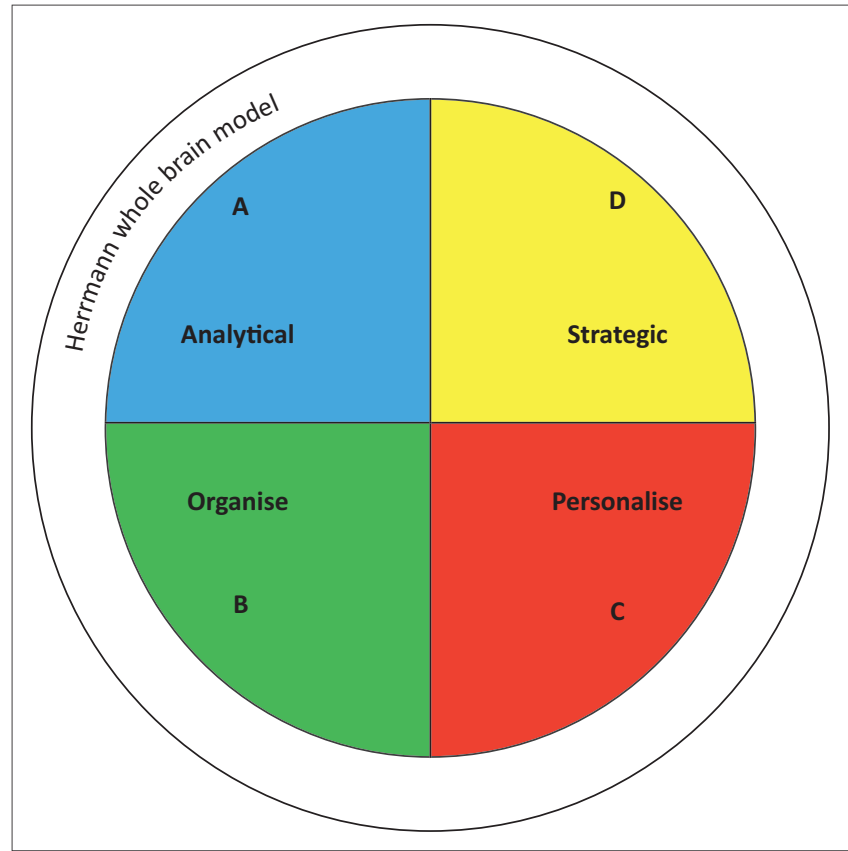

Source: Adapted from Herrmann, N. (1996). The whole brain business book. New York: McGraw-Hill.

FIGURE 3: Core of the future-focused whole-brain model.

processes of administrative professionals who are expected to apply 20th-century skills and knowledge in a new world of work. Therefore, administrative professionals have to adjust from the execution of duties on the instruction of managers, as was expected in the service economy, to the demands of the experience economy to the skills of innovation and creativity. The relationship economy has prompted a shift towards another conformation, namely interpersonal and intuitive skills. Consumers are sharing their experiences of trademarks and services on social media. Therefore, social media create a different platform for administrative professionals to communicate and connect with clients. Flexibility and adaptability are skills required not only for the sharing economy but also for transition into 4IR, which is driven by extreme automation and connectivity through artificial intelligence. Administrative professionals should obtain a skill set which is beyond that of functional skills to execute their role effectively.

\section{Research design and methods Research approach}

The research followed an embedded mixed methods approach. The research was conducted in three phases. In phase 1, international and national investigations were conducted through email enquiries sent to various international and national associations of administrative professionals to establish whether they had undergone a formal skillset survey to determine current gaps in the competencies and capabilities of administrative professionals. In the international investigation, the International Association of Administrative Professionals (IAAP) and a committee member of the Association of Administrative Professionals, New Zealand (AAPNZ) provided data that had emerged from their respective skillset surveys.
The national investigation revealed that the administrative professional associations had not conducted a formal skillset survey, and a national skills survey was therefore conducted in Phase 3. Phase 2 consisted of a review of the literature to uncover the gaps in knowledge and the lack of skills according to the mental preferences of Herrmann's Whole Brain ${ }^{\circledR}$ model. A sequential exploratory design was employed for Phase 3 to produce the quantitative data that emanated from a structured survey questionnaire which assessed what impact the key drivers of change had on administrative professionals becoming whole-brain thinkers, so as to execute their role more effectively. An analysis was undertaken, where descriptive statistics were used to source primary data. The qualitative data that emerged from the semi-structured interviews that investigated the required future competencies and capabilities of administrative professionals were then analysed by means of qualitative content analysis. The three-phase data-gathering process was followed to construct a future-focused whole-brain success profile to demonstrate the impact of global key drivers of change in terms of the future functional skills, the essential skills and the emerging skills required for optimal effectiveness.

\section{Research participants}

Only Phase 3 included participants. Reporting on quantitative and qualitative data was therefore captured in this phase. Members of the Association for Office Professionals of South Africa (OPSA) completed the survey questionnaire online. From the target population $(N=354)$, a total of 219 responses were received, representing a response rate of $62 \%$. A pilot test was conducted with 10 respondents from the target population, who were dispersed over a wide geographical area. For the purpose of the semi-structured interviews, two administrative professionals from the industry were dentified and invited by the Association for OPSA to participate. The chairperson of the department of Office Management and Technology's academic advisory committee at the Tshwane University of Technology identified an academic advisory committee representative to participate. The remainder of the sample group, namely the education and training professional, manager and subject curriculum practitioner, was made up of professionals from the Tshwane University of Technology.

\section{Measuring instruments}

A survey questionnaire was designed for Phase 3 as a measuring instrument to gather data based on the national skills survey. The questionnaire was divided into three sections: Section A elicited biographical information, such as age, geographical location of employer, current position, duration of current or related work experience, industry, professional membership, highest level of education and enrolment status. Section B was compiled based on the data emanating from the international investigation (Phase 1), future-focused models, such as the Future Work Skills 2020 of Davies et al. (2011) and Burton and Shelton's (2010) Lifelong 
Learning Skills, and a literature review. The visual analogue scale (VAS) was applied to this section (Green \& Taylor, 2009; Hasson \& Arnetz cited in Musangu \& Kekwaletswe, 2012, p. 63-64; Svensson, 2001). Section B had the following categories, with four to five questions for each category:

1. office administration, and organisational and time management

2. information and communication technology

3. management of meetings

4. communication

5. interpersonal skills, such as team working, project and event management, supervising of staff, conflict resolution, public relations and customer service/ relations

6. thinking skills, such as problem-solving, commercial awareness, personal commercial awareness development and outside-the-box/innovative thinking

7. personal qualities, such as social adaptability and selfmanagement

8. emotional intelligence.

Section C comprised the following two open-ended questions:

1. Are there any other skills that you regard as essential skills for future success that are not mentioned in the questionnaire?

2. In which of these do you need development?

\section{Inferential statistics}

The alternative hypothesis $\left(\mathrm{H}_{1}\right)$ postulated that there is a relationship between the demographic profile of administrative professionals in South African companies and the current level of knowledge and skills. The findings revealed that there was a significant relationship between the following:

1. Age and office administration, organisational, and time management, information and communication technology and web-based applications (Table 1). Considering that most of the respondents are employed as personal assistants, it could be possible that they are exposed to higher levels of knowledge and skills regarding the mentioned questions. In addition, the significant relationship could be attributed to the perception that the current multigenerational workforce has about learning.

2. Length of service and office administration, and organisational and time management. Given the current multigenerational nature of the workforce, the only assumption that could be made regarding the significant relationship depicted in Table 2 is similar to that indicated above (see Table 1).

\section{Data collection procedure}

The software SurveyMonkey ${ }^{\mathrm{TM}}$ served as a diagnostic and anonymous online assessment tool for collecting quantitative data. The OPSA distributed the hyperlink of SurveyMonkey ${ }^{\mathrm{TM}}$ website to their members through their Terrific Tuesday electronic newsletter.
TABLE 1: Relationship between age and items.

\begin{tabular}{lc}
\hline Item description of null hypothesis & $p$ \\
\hline $\begin{array}{l}\text { The distribution of office administration, and organisational and } \\
\text { time management is the same across categories of age }\end{array}$ & $0.038^{*}$ \\
$\begin{array}{l}\text { The distribution of information and communication technology } \\
\text { is the same across categories of age }\end{array}$ & $0.023^{*}$ \\
$\begin{array}{l}\text { The distribution of web-based applications is the same across } \\
\text { categories of age }\end{array}$ & $0.011^{*}$ \\
\hline
\end{tabular}
categories of age

*, Significant at 0.05 error rate.

TABLE 2: Relationship between length of service and items. Item description of null hypothesis

The distribution of office administration, and organisational and time management is the same across categories of tenure

*, Significant at 0.05 error rate.

Qualitative data were gathered by means of semi-structured interviews that addressed the main categories of Section B of the survey questionnaire. Invitations to participate in the survey were sent by means of email invitations to prospective participants outlining the purpose of the investigation. The participating professionals were interviewed in their respective work environments. The recording of the interviews was carried out with an audio-recording pen.

\section{Data analysis}

The skills and knowledge gaps that emerged from the three data-gathering phases were categorised according to the four thinking preferences of Herrmann's Whole Brain ${ }^{\circledR}$ model, namely the international investigation in Phase 1, and the literature review in Phase 2. Phase 3 comprised quantitative findings from the national skills survey and qualitative findings that emerged from semi-structured interviews.

With regard to the analysis of qualitative data by means of qualitative content analysis, eight main themes and related sub-themes of the semi-structured interview questionnaire were identified from the survey questionnaire. The entire transcribed text was arranged into themes and categories using the software ATLAS.ti ${ }^{\mathrm{TM}}$ version 8 , and codes were assigned.

The results from the survey questionnaire, Phase 3, were analysed by means of descriptive statistics, which employed the Statistical Package for Social Sciences (SPSS) (Couper, Tourangeau, Conrad, \& Singer, 2006). The descriptive statistics, in this case the mean value, were obtained from the interval-scaled items of the current knowledge and skills in category B. Frequencies were analysed together with inferential statistics. A Cronbach's alpha analysis and tests for significant differences were performed. It is evident from the data in Table 3 that 9 of the 10 main categories in category B were reliable for testing inter-item consistency, that is Cronbach's alpha $(\alpha)>0.7$.

\section{Ethical clearance}

The researcher obtained written consent from the Research Ethics Committee of the Cape Peninsula University of 
TABLE 3: Cronbach's alpha $(\alpha)$ for the sub-scales of the measurement.

\begin{tabular}{lcc}
\hline Instrument sub-dimension & $\begin{array}{c}\text { Cronbach's } \\
\text { alpha }(\boldsymbol{\alpha})\end{array}$ & $\begin{array}{c}\text { Number } \\
\text { of items }\end{array}$ \\
\hline Office administration, and organisational and time management & 0.8743 & 4 \\
Information and communication technology & 0.8465 & 5 \\
Internet web-based applications & 0.8223 & 3 \\
Management of meetings & 0.9305 & 5 \\
Communication & 0.8958 & 3 \\
Interpersonal skills & & \\
Team working, project and event management & 0.8635 & 5 \\
Supervising of staff & 0.9199 & 4 \\
Conflict resolution & 0.9259 & 3 \\
Public relations and customer service/relations & 0.9180 & 3 \\
Thinking skills & & \\
Problem-solving & 0.9047 & 4 \\
Commercial awareness & 0.9114 & 4 \\
Outside-the-box/innovative thinking & 0.9051 & 3 \\
Personal qualities & & \\
Social adaptability & 0.9239 & 5 \\
Self-management & 0.8435 & 4 \\
Emotional intelligence & 0.9053 & 4 \\
\hline
\end{tabular}

Technology to engage with human participants from public and private sectors. Written consent was also obtained from an association for administrative professionals, namely the Association for OPSA that they would distribute the survey questionnaire to their members on behalf of the researcher for the quantitative data-gathering process. Participants agreed to participate in the survey by means of an online implied consent.

\section{Limitations}

Negotiations with regard to the distribution of the survey questionnaire by the professional association, OPSA proved a time-consuming process. The researcher distributed the letter of informed consent to chief executive officers (CEOs) of three professional associations. Communication with them was a time-consuming process, considering that being the CEO of a professional association was not their primary occupation. Therefore, responses to emails were delayed, with the result that the period for approving the informed consent was extended. This trend was also experienced during the pilot study and the comprehensive survey. The professional association had to post numerous reminder emails, and consequently the window period had to be extended. In view of the fact that maximum participation in the survey was limited to one province, greater participation in other eight provinces would have added value to the study. Another limitation was that the study was based on a self-assessment (respondents' own perception of their current proficiency), and not an assessment of skills. Regarding assessment of skills, it should be taken into consideration that Van Antwerpen (2013) found that testing of skills and competencies could be time-consuming. Low response rate from the target population could also be considered a limitation of the study.

\section{Ethical consideration}

Ethical clearance to conduct the study was obtained from the Faculty of Business and Management Sciences' Research Ethics Committee (clearance number: 212306383).

\section{Findings Phase 1}

The findings revealed that although skills and knowledge gaps were reflected in all four thinking quadrants, the impact of global and national key drivers of change reflected that skills were also required in the right-brain thinking quadrants, for example working independently, adaptability, virtual meeting management, creative ways to address projects and problems, human resource processes, supervision and training of co-workers, team participation and a different level of oral, written and interpersonal communication.

\section{Phase 2}

The results derived from the literature review in Phase 2 supported the findings of an international investigation conducted in Phase 1. However, the following additional skills and knowledge gaps were identified in Phase 2:

- Information and communication technology and webbased applications, data analysis and presentation, databased decisions, communication awareness of the knowledge business and trends managing information in terms of acquire, evaluate, organise, maintain, interpret and communicate, technology knowledge of teleconferencing, Skype and software for virtual meetings. These thinking processes utilise technical skills (what is needed) to serve as a tool for tasks, for example for research to be effective (what to do) and are related to the upper left thinking processes (Quadrant A).

- Managing resources by identifying, organising and planning and allocating time, money, materials and facilities. Thinking in this quadrant, namely the lower left thinking processes (Quadrant B) asks 'how to' in order to succeed in, for example, office administration, and organisational and time management.

- Emotional intelligence, which includes interpersonal skills such as emotional and social skills, which promote working with people and building relationships related to the lower right-thinking processes, namely in Quadrant C.

\section{Phase 3}

In Table 3, the results of the current level of skills and knowledge are ranked in the descending order of the mean score. For the purpose of determining the mean value of the skills gap, all results of skills in the respective categories with a mean value lower than 6 were considered as skills gaps. It is noticeable from the summary that the respondents indicated their skills as relatively high on the VAS, except in the category of web-based applications, which yielded a relatively lower value compared to other categories. 
TABLE 4: Summary of the mean values of all categories.

\begin{tabular}{|c|c|c|c|c|c|}
\hline Category & $N$ & Minimum & Maximum & Mean value & Standard deviation \\
\hline Emotional intelligence & 157 & 3.25 & 11.00 & 9.2935 & 1.24713 \\
\hline Personal qualities & 181 & 3.75 & 11.00 & 9.2868 & 1.43781 \\
\hline Communication & 192 & 4.00 & 11.00 & 9.2500 & 1.48289 \\
\hline Interpersonal skills & 192 & 4.53 & 11.00 & 8.8432 & 1.32089 \\
\hline Office administration, and organisational and time management & 201 & 4.00 & 11.00 & 8.6493 & 1.41442 \\
\hline Thinking skills & 190 & 3.77 & 11.00 & 8.5130 & 1.43284 \\
\hline Information and communication technology & 199 & 3.60 & 11.00 & 8.1731 & 1.58821 \\
\hline Web-based applications & 198 & 1.00 & 11.00 & 5.3190 & 2.62369 \\
\hline Valid $N$ (list-wise) & 157 & - & - & - & - \\
\hline
\end{tabular}

In brief, the national skills survey conducted amongst administrative professionals in private and the public sectors determined the current gaps in competencies and capabilities to comply with the future world of work. Phase 3 of the datagathering process was thus based on the skills and knowledge gaps that emerged from the national skills survey and the semi-structured interviews. It is evident that the results of the national perspective obtained from the skills survey were not consistent with the results emanating from the international investigation and literature study. Overall, there appears to be no shortage of skills in the South African context. Thus, the respondents were of the opinion that they were up to standard as far as future skill requirements were concerned. The only skill shortages identified were in the category of web-based applications, as these responses recorded the lowest overall mean value, namely 5.3190.

In the category of information and communication technology, some skills are regarded as not necessary skills gaps but these might hinder respondents in the future world of work because these items received lower mean values. These are electronic records management (7.92), social networking sites (7.83), Internet phone services (7.43) and conducting research (7.20). According to the literature, these technology skills are vital skills for the future world of work. It is important to note that the results obtained are a reflection of respondents' self-assessment of their level of proficiency in these skills categories. A performance-based assessment might have yielded different results. Inconsistent with these findings are the findings of computer literacy skills that emanated from a study conducted by Van Antwerpen and Ferreira (2016) amongst administrative employees in the Gauteng public service. The findings of the practical test revealed that the level of competency was very low and that there was a lack of typing and keyboard skills.

Taking into account the impact of future skill requirements, as reflected in the guides for the key drivers of change (see Figure 1), it could be deduced that the future skill requirements have not had a negative impact at national level. Although no significant knowledge and skill gaps were perceived, according to the results of the national skills survey, as depicted in Table 1, it was found that the mentioned skills would continue to be important skills needed to remain effective in the next 10 years. It could be assumed that at the rate at which technology is changing, gaps in skills are most likely to arise, considering the feedback received from the open-ended questions regarding the increasing need for additional training or training at an advance level or for the purpose of improving current skills.

Considering the relatively lower mean value (5.3190) (see Table 1) for the category of web-based applications as well as for the category of demand for training, namely $24.02 \%$ in skills related to web-based applications, it seems that skills in web-based applications are regarded as a gap.

\section{Summary of findings}

Figure 4 depicts a future-focused model for whole-brain thinking, which shows the impact of revolutionary developments in information and communication technology on the current work environment of administrative professionals and the future role and accompanying thinking processes. The knowledge and skills required by administrative professionals for optimal efficiency were determined during the data-gathering process, namely in Phases 1, 2 and 3. The knowledge and skills required to comply with and perform according to the demands of the changing world of work have been categorised as functional future skills, which constitute the first layer around Herrmann's four quadrants at the core of the future-focused model (see Figure 4), followed by essential future skills, with emerging future skills in the outer layer.

The four quadrants are displayed in Figure 4, namely analytical (A), organise (B), personalise (C) and strategic (D), which show different thinking preferences. The activities allocated to these four thinking profiles are as follows:

Quadrant A represents activities that involve analysing, dissecting, solving problems logically and getting facts. These activities are preferred by the 'theorists', or the rational self. The organisers, or the safekeeping self, of Quadrant B prefer detailed, sequential, structured and linear activities. Activities that consider people, team participation, emotional intelligence and social and humanistic interests are represented in Quadrant C. These activities are preferred by humanitarians, or the feeling self. Intuitive, holistic, conceptualising, adventurous and risk-taking activities are preferred by innovators, or the experimental self, of Quadrant D (Herrmann, 1996, pp. 20-23). 
TABLE 5: Summary of frequency distribution and codes.

\begin{tabular}{|c|c|c|c|}
\hline Theme & Category & Code & Frequency \\
\hline \multirow{2}{*}{$\begin{array}{l}\text { Office administration, and } \\
\text { organisational and time management }\end{array}$} & \multirow[t]{2}{*}{ N/A } & Technology at your fingertips & 9 \\
\hline & & Adapting to global changes & 8 \\
\hline \multirow{5}{*}{$\begin{array}{l}\text { Information and communication } \\
\text { technologies }\end{array}$} & \multirow[t]{5}{*}{ N/A } & Computer skills as a necessity & 4 \\
\hline & & Global changes and adaptability & 4 \\
\hline & & The fall of the third party & 4 \\
\hline & & Collaborative software & 2 \\
\hline & & Skilled administrative personnel & 2 \\
\hline \multirow[t]{6}{*}{ Management of meetings } & \multirow[t]{6}{*}{ N/A } & Online collaborative information processing & 6 \\
\hline & & Automated systems for minutes & 5 \\
\hline & & Formal agendas as key responsibility & 3 \\
\hline & & Virtual meetings as the way forward & 3 \\
\hline & & ICT knowledge of the utmost importance & 1 \\
\hline & & Minutes as future record keeping process & 1 \\
\hline \multirow{6}{*}{$\begin{array}{l}\text { Oral, written and interpersonal } \\
\text { communication to convey and } \\
\text { articulate knowledge and } \\
\text { information in effective and } \\
\text { appropriate ways to meet } \\
\text { everyone's needs }\end{array}$} & \multirow[t]{6}{*}{ N/A } & Digital software assistance & 6 \\
\hline & & Importance of communication skills & 3 \\
\hline & & Professional oral communication & 3 \\
\hline & & Technology depersonalises human interaction & 3 \\
\hline & & Online migration & 2 \\
\hline & & Administrative professional as first-line contact & 1 \\
\hline \multirow[t]{11}{*}{ Interpersonal skills } & \multirow{6}{*}{$\begin{array}{l}\text { Teamwork, project and event } \\
\text { management }\end{array}$} & Teamwork as critical skill & 5 \\
\hline & & Problem-solving skills & 4 \\
\hline & & Event management as a critical skill & 4 \\
\hline & & Interpersonal skills are critical & 2 \\
\hline & & Responsibility to co-ordinate between divisions & 2 \\
\hline & & Team work on SharePoint & 2 \\
\hline & \multirow{2}{*}{$\begin{array}{l}\text { Supervising staff that contribute towards } \\
\text { an improved workflow }\end{array}$} & Supervising staff to be skillfull & 4 \\
\hline & & Emotional intelligence as crucial skill for communication purposes & 2 \\
\hline & \multirow{3}{*}{$\begin{array}{l}\text { Managing conflict to promote effective } \\
\text { working relationships }\end{array}$} & Professional communication & 3 \\
\hline & & Office politics as an element of conflict & 1 \\
\hline & & Power relations as problematic & 1 \\
\hline \multirow[t]{7}{*}{ Thinking skills } & $\begin{array}{l}\text { Problem-solving skills to contribute } \\
\text { towards productive outcomes }\end{array}$ & Problem-solving skills & 6 \\
\hline & Knowledge of commercial awareness & Commercial awareness & 5 \\
\hline & \multirow{3}{*}{$\begin{array}{l}\text { The development of personal commercial } \\
\text { awareness }\end{array}$} & Proper training in commercial awareness & 6 \\
\hline & & Awareness of working context & 2 \\
\hline & & Aware of social footprint & 1 \\
\hline & \multirow[t]{2}{*}{ Outside-the-box/innovative thinking } & Space for innovative thought & 4 \\
\hline & & Teaching innovation thinking & 4 \\
\hline \multirow[t]{4}{*}{ Personal qualities } & \multirow[t]{2}{*}{ Socially adept } & Personal qualities as crucial factor for adaptability & 7 \\
\hline & & Adaptabilty is crucial for career & 4 \\
\hline & \multirow[t]{2}{*}{ Independence and self-management } & Self-management is key & 5 \\
\hline & & Independence is key & 3 \\
\hline \multirow[t]{2}{*}{ Emotional intelligence } & \multirow[t]{2}{*}{ N/A } & El is crucial for communication processing & 7 \\
\hline & & Technologies as a barrier for El & 3 \\
\hline
\end{tabular}

N/A, not applicable.

The functional future skills circle displays the basic skills and knowledge and the interpersonal skills that administrative professionals require to execute their work effectively, irrespective of the socio-economic, geopolitical and demographic key drivers of the changing economy. It is evident that administrative professionals at functional level require thinking in all four quadrants.

A skillset much different from the functional future skillset is required in the circle representing essential future skills. A difference worth mentioning between the essential future skills layer and the functional future skills layer of Quadrant A is that a more advanced computational skillset is required in the former layer, for example audio and video technology, digital technology, system thinking, data analysis and presentation, and data-based decisions. More resources have to be allocated in the essential future skills layer of Quadrant B, namely organising time, assignments and projects, and streamlining tasks. Skills such as training and mentoring of co-workers, effective negotiation, listening skills, and social and emotional intelligence are essential skills of Quadrant C. Being flexible with working 


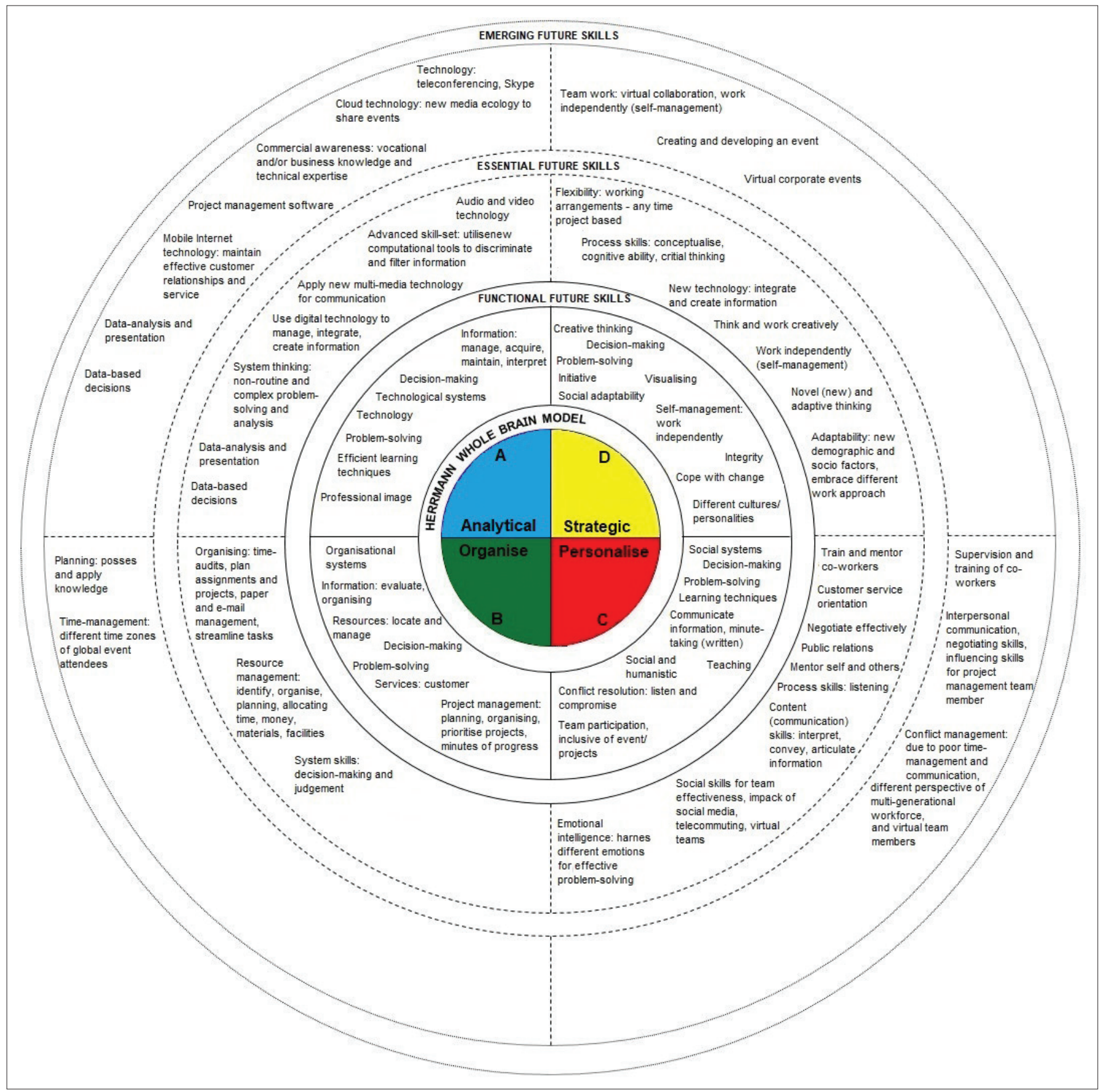

FIGURE 4: Future-focused whole-brain model.

arrangements, process skills, such as conceptualising and critical thinking, and novel and adaptive thinking differentiate the two layers of Quadrant D.

From the emerging future skills circle of Quadrant A, it is apparent that the biggest impact is on the field of information and communication technology in terms of cloud technology, project management software and mobile Internet technology. Quadrant C shows that conflict management in terms of poor time management and communication is an emerging future skill. Another emerging future skill of creating and developing a virtual corporate event is evident in Quadrant D.

\section{Recommendations}

This section provides recommendations for curriculum development and continuous professional development.

\section{Recommendations for curriculum development}

Considering the rapid pace of technology development, and the profession of administrative professionals being mainly skills-based, the current formal training of 3 years should be reconsidered. By the time administrative professionals enter the workplace, they run the risk of their skills being outdated. The curriculum should be adapted to allow for shorter 
modular credit-bearing skill programmes in line with the latest trends in technology. This would provide administrative professionals with a more flexible approach to improve their qualifications.

Bearing in mind that the highest qualification of most South African administrative professionals is a diploma, this recommendation could address the need for improvement in their qualifications. As discussed in Phase 1, this would align their level of qualifications with the international benchmark, namely completing a higher-level qualification to fill gaps in knowledge.

\section{Recommendations for continuous professional development}

The role of administrative professionals has definitely changed over the years, and evidence exists that their role would continue to evolve in the future. To adapt to and manage that change, a variety of avenues are available for professional development, for example training courses available through their employer, work shadowing, webinars or podcasts and attending conferences.

Opportunities for continuous training and development should be provided by means of short-learning programmes and refresher courses to allow administrative professionals acquire necessary skills of advanced levels. This would enable them to function and perform at an advance level in accordance with their new and more challenging and diversified roles. Although Van Antwerpen (2013) believes that continuous training and development of administrative employees is important, she mentions some of the challenges experienced in South Africa's public service environment that cause training not adding value to performance. These challenges are inadequate employee training and development, lack of appropriate skills assessment, and additional dimension of strategic value. Businesses in private and public sectors should therefore continuously invest in training and development to ensure reskilling of administrative employees.

Of particular importance is continuous training and development in the areas of advanced web-based applications, emotional intelligence, flexibility, adaptability to change, leadership and presentation skills. These opportunities should make provision for administrative professionals' preferred methods of learning as indicated in the survey, that is, to obtain experience in their work environment, and to obtain training away from the office by means of books, articles and manuals.

In this regard, application of HBDI could assist administrative professionals to identify their areas of strength and the areas that they need to develop so that they could select relevant continuous professional development opportunities.

In addition to their usual responsibilities, administrative professionals are expected to take on a variety of new tasks, and they, therefore, require continuous professional development in these new tasks. Examples of these tasks include Internet research and market analysis, office management, marketing, human resources, finance, event management, support for multiple leaders or executives, making independent decisions up to a specified monetary value, holding specific industry experience, leading a project team and managing a budget.

\section{Recommendations for further study}

The findings related to the skills category on information and communication technology are inconsistent with the findings of a computer literacy skills assessment that emanated from the study conducted by Van Antwerpen and Ferreira (2016) amongst administrative employees in the Gauteng public service. This inconsistency might be because of the fact that respondents did not reveal their actual computer literacy skills in a survey questionnaire used in this research. It is therefore recommended that additional research be conducted by means of practical assessments to determine the actual levels of computerbased competency.

\section{Conclusion}

Based on the results of the study, the future-focused success profile for administrative professionals illustrates that they have to become whole-brain thinkers, incorporating rightbrain thinking in order to execute their roles effectively. Thus, the future-focused whole-brain model offered in this study allows for optimal effectiveness of administrative professionals in the future world of work. In addition, owing to the focus of the study on the new world of work, the findings could be related to most of the occupations.

\section{Acknowledgements Competing interests}

The authors have declared that no competing interests exist.

\section{Authors' contributions}

Dr H.H. Herbst and Prof. C.G. Iwu supervised the first author's (A.J.V.) doctoral study.

\section{Funding information}

The financial assistance of the National Research Foundation (NRF) towards the research is acknowledged.

\section{Data availability statement}

Data sharing is not applicable to this article as no new data were created or analysed in this study.

\section{Disclaimer}

The views and opinions expressed in this article are those of the authors and do not necessarily reflect the official policy or position of any affiliated agency of the authors. 


\section{References}

African Union Commission. (2015). African Agenda 2063: The Africa we want Retrieved from https://www.un.org/en/africa/osaa/pdf/au/agenda2063.pdf.

AlGhraibeh, A.M.A. (2015). Learning and thinking styles based on whole brain theory in relation to emotional intelligence. Open Access Library Journal, 2(5):1-14. Retrieved from https://doi.org/10.4236/oalib.1101436.

Anderson, J.Q., \& Rainie, L. (2012). Millennials will benefit and suffer due to their hyper connected lives. Washington, DC: Pew Research Center. Retrieved from https:// www. pewinternet.org/2012/02/29/millennials-will-benefit-and-suffer-due-toWwW.pewinternet.org/2012/02/.
their-hyperconnected-lives-2/.

Bloem, J., Van Doorn, M., Duivestein, S., Excoffier, D., Maas, R., \& Van Ommeren, E. (2014). The fourth industrial revolution: Things to tighten the link between IT and OT. Sogeti VINT. Retrieved from https://www.fr.sogeti.com/globalassets/global/ downloads/reports/vint-research-3-the-fourth-industrial-revolution.

Burton, S., \& Shelton, N. (2010). Office procedures for the 21st century (8th edn.). Upper Saddle River, NJ: Pearson Education.

Bussin, M.H.R., \& Brigman, N. (2019). Evaluation of remuneration preferences of knowledge workers. SA Journal of Human Resource Management, 17:1-10. Retrieved from https://doi.org/10.4102/sajhrm.v17i0.1075

Cassidy, S. (2004). Learning styles: An overview of theories, models, and measures. Educational Psychology, 24(4), 419-444. Retrieved from https://acdowddesigns. com/sfsu_860_11/LS_OverView.pdf.

Cathsseta. (2013). Skills development facilitator guide. Retrieved from https://www. cathsseta.org.za/.

Cilliers, J., Hughes, B., \& Moyer, J. (2011). African futures 2050: The next forty years. ISS Monograph 175. Pretoria, South Africa: Institute for Security Services. Retrieved from https://www.issafrica.org/publications.

Coffield, F., Moseley, D., Hall, E., \& Ecclestone, K. (2004). Learning styles and pedagogy in post-16 learning: A systematic and critical review. London: Learning and Skills Research Centre. Retrieved from https//www.LSRC.ac.uk.

Couper, M.P., Tourangeau, R., Conrad, F.G., \& Singer, E. (2006). Evaluating the effectiveness of visual analog scales: A web experiment. Social Science Computer effectiveness of visual an
Review, 24(2), 227-245.

Davies, A., Fidler, D., \& Gorbis, M. (2011). Future work skills 2020. Palo Alto, CA: Institute for the Future for the University of Phoenix Research Institute. Retrieved from https://www.iftf.org/uploads/media/SR-1382A_UPRI_future_work_skills sm.pdf.

De Boer, A.-L., Du Toit, P.H., \& Bothma, T.J.D. (2015). Activating whole Brain innovation: A means of nourishing multiple intelligence in higher education TD The Journal for Transdisciplinary Research in Southern Africa, 11(2), 55-72. Retrieved from https://repository.up.ac.za/bitstream/handle/2263/51114/DeBoer Retrieved from https://repository.up

De Boer, A.-L., \& Van den Berg, D. (2001). The value of the Herrmann brain dominance instrument (HBDI) in facilitating effective teaching and learning of criminology. Acta Criminologica, 14(1), 119-129. Retrieved from https://citeseerx.ist.psu.edu/ viewdoc/download?doi=10.1.1.505.2882\&rep=rep1\&type=pdf

Department of Higher Education and Training. (2016). National skills development strategy (NSDS III) progress report 2011-2016. Pretoria, South Africa: Department of Higher Education and Training. Retrieved from www.wrseta.org.za/.

Domeyer, D. (2005). The office of the future presents a world of opportunity for administrative professionals. Office Pro, 65(16), 12. Retrieved from https://www. iaap-hq.org

Ensminger, D.C., Surry, D.W., Porter, B.E., \& Wright, D. (2004). Factors contributing to the successful implementation of technology innovations. Journal of Educational Technology \& Society, 7(3), 61-72. Retrieved from https://www.learntechlib. $\mathrm{org} / \mathrm{p} / 75445 /$

Fear, U., Botha, N., Young, C., Rautenbach, J., \& Groenewald, F. (2009). Skills development: Developing people for the future of business. New York, NY: Deloitte Touche Tohmatsu. Retrieved from https://www2.deloitte.com/za/en.html.

Ferreira, E., \& Van Antwerpen, S. (2011). Productivity and morale of administrative employees in the South African public service. African Journal of Business Management, 5(32), 12606-12614. Retrieved from https://www. academicjournals.org/AJBM.

Ferreira, H., \& Teixeira, A.A.C. (2013). 'Welcome to the experience economy': Assessing the influence of customer experience literature through bibliometric analysis. FEP Working Papers. Porto, Portugal: University of Porto. Retrieved from https://wps. fep.up.pt/wps/wp481.pdf.

Green, N., \& Taylor, K. (2009). Use of the visual analogue scale (VAS) for assessment of discomfort in office workers. Wellnomics ${ }^{\circ}$ White Paper. Christchurch, New Zealand: Wellnomics Limited. Retrieved from https://www.workpace.com/assets/ for-assessment-of-discomfort-in-office-workers.pdf.

Harypursat, R. (2005). The thinking styles of IT students and practitioners. Unpublished Master's thesis, University of KwaZulu-Natal, Durban, South Africa.

Herrmann, N. (1995). The creative brain. Kingsport, TN: Quebecor Printing Book Group.

Herrmann, N. (1996). The whole brain business book. New York: McGraw-Hill.

Herrmann, N., \& Herrmann-Nehdi, A. (2015). The whole brain business book (2nd edn.) New York: McGraw-Hill.

Hollis-Turner, S.L. (2008). Higher education business writing practices in office management and technology programmes and in related workplaces. Unpublished Master's thesis, Cape Peninsula University of Technology, Cape Town, South Africa.
Hosany, S., \& Witham, M. (2010). Dimensions of cruisers' experiences, satisfaction and intention to recommend. Journal of Travel Research, 49(3), 351-364. Retrieved from https://citeseerx.ist.psu.edu/viewdoc/download?doi=10.1.1.1032.4933\&re from https://citese

Howes, A. (2016). The relevance of skills to innovation during the British Industrial Revolution, 1651-1851. Rhode Island: Brown University. Retrieved from https:// eh.net/eha/wp-content/uploads/2016/08/Howes.pdf.

Huitt, W.G. (2007). Success in the conceptual age: Another paradigm shift. Paper presented at the 32nd Annual Meeting of the Georgia Educational Research Association, Savannah, GA. Retrieved from https://edpsycinteractive.org/wpcontent/uploads/2015/11/conceptual-age.pdf.

Jensen, E. (2007). Introduction to brain-compatible learning (2nd edn.). Thousand Oaks, CA: Corwin Press.

Kamel, J.A.N., Melo, A.M., De Souza, B.M.L., Lima, J.M.B., \& Lopes, P.H.D.-M. (2008), Experience economy. Paper presented at the IV National Congress of Excellence in
Management on Environmental Responsibilities of Organisations in Niteroi, Brazil. Retrieved from https://citeseerx.ist.psu.edu/viewdoc/download?doi=10.1.1.624. Retrieved from https://citesee
$6797 \&$ rep=rep1\&type=pdf.

Kruger, J. (2008). Linkages between emotional intelligence and coping strategies in mastering new educational technologies. Unpublished Doctoral thesis, University of Pretoria, Pretoria, South Africa.

Kumar, S. (2014). A study on cognitive styles of J. B. T. trainees in Hamirpur district of Himachal Pradesh State with respect to gender, locale, stream, and family status. European Academic Research, I/(3), 3770-3788. Retrieved from https://www. euacademic.org/UploadArticle/650.pdf.

Martins, M.J. (2015). Ned Herrmann model: Team innovation by complementarity and diversity. Retrieved from https://fenix.tecnico.ulisboa.pt/downloadFile/ 563568428717782/19\%20Ned\%20Herrmann\%20MJM.pdf.

Musangu, L.M., \& Kekwaletswe, R.M. (2012). Comparison of Likert scale with visual analogue scale for strategic information systems planning measurements: A preliminary study. Proceedings of the IADIS International Conference Information Systems 2012, is 2012. Retrieved from https://www.researchgate.net/ publication/289951107_Comparison_of_likert_scale_with_visual_analogue_scale_ for_strategic_information_systems_planning_measurements_A_preliminary_study.

Neethling, K., \& Rutherford, R. (2005). Creativity uncovered. Midrand, South Africa: Solutionsfinding.

Neethling, K., \& Rutherford, R. (2009). Am I clever or am I stupid? Vanderbijlpark, South Africa: Carpe Diem Boeke.

OECD. (2000). The service economy. Science Technology Industry (STI) Business and Industry Policy Forum Series. Paris, France: OECD. Retrieved from https://www. oecd.org/sti/ind/2090561.pdf.

Pine II, B.J., \& Gilmore, J.H. (1998). Welcome to the experience economy. Harvard Business Review, 76(4), 97-105. Retrieved from https://www.hbsp.harvard.edu.

Pine II, B.J., \& Gilmore, J.H. (2001). Welcome to the experience economy. It's no longer just about healing: Patients want a personal transformation. Health Forum Journal, 44(5), 10-6, 2. Retrieved from https://www.ncbi.nlm.nih.gov/ pubmed/10181589.

Pink, D.H. (2005). A whole new mind: Moving from the information age to the conceptual age. New York: Penguin Group.

Pompidou, A. (2007). Scenarios for the future: How might IP regimes evolve by 2025 ? What global legitimacy might such regimes have? Munich: European Patent Office.

Quilligan, A. (2015). The fourth industrial revolution: When digital technology meets the shop floor. Accenture Industrial Software Solutions. Fifth Cambridge Wireless Prestigious Lecture on 12 February 2015. Retrieved from https://www. cambridgewireless.co.uk/news/2015/feb/12/48540-accentures-aiden-quilligantakes-to-the-floo/.

Rorbak, S.C. (2012). The elite secretary: The definitive guide to a successful career. Bloomington, IN: iUniverse.

Rowson, J., \& McGilchrist, I. (2013). Divided brain, divided world: Why the best part of us struggles to be heard. Retrieved from https://www.thersa.org/globalassets/ of us struggles to be heard. Retrieved from https:
$\mathrm{pdfs} /$ blogs/rsa-divided-brain-divided-world.pdf.

Samuel, R.E., \& Kohun, F.G. (2010). Managing perceived coping behavior while mentoring doctoral students. International Journal of Doctoral Studies, 5:29-37. Retrieved from https://ijds.org/Volume5/IJDSv5p029-037Samue291.pdf.

Seltzer, K., \& Bentley, T. (1999). The creative age: Knowledge and skills for the new economy. London: Demos. Retrieved from https://www.demos.co.uk/files/ theCreativeage.pdf.

Silke, D. (2011). Tracking the future: Top trends that will shape South Africa and the world. Cape Town, South Africa: Tafelberg.

Smith, A.T. (n.d.). Literacy in the conceptual age and the future of the agenda for education in a democracy. Retrieved from https://www.units.miamioh. Literacy $\% 20$ in $\% 20$ the $\% 20$ Conceptual $\% 20$ Age $\% 20$ Smith $\% 2010-09$.pdf.

Stanfield, I., \& O'Hare, K. (2013). The rise of the relationship economy: What it means for brands and brand research. Retrieved from https://www.gfk.com/en-gb/ search/search-results/?q=rise $\% 20$ of $\% 20$ the $\% 20$ relationship $\% 20$ economy $\% 20$ $-\% 20$ what $\% 20$ it $\% 20$ means $\% 20$ for $\% 20$ brands $\% 20$ and $\% 20$ brand $\% 20$ research.

Sternberg, R.J. (1990). Thinking styles: Keys to understanding student performance. The Phi Delta Kappan, 71(5), 366-371. Retrieved from https://www.jstor.org/ stable/20404156.

Sternberg, R.J. (1994). Allowing for thinking styles. Educational Leadership, 52(3), 36-40. Retrieved from https://eric.ed.gov/?id=EJ492910.

Stum, J. (2009). Kirton's adaption-innovation theory: Managing cognitive styles in times of diversity and change. Emerging Leadership Journeys, 2(1), 66-78. Retrieved from https://pdfs.semanticscholar.org/25b9/017bc53f30f202bde1769 e4a440703d67081.pdf. 
Svensson, E. (2001). Guidelines to statistical evaluation of data from rating scales and questionnaires. Journal of Rehabilitation Medicine, 33(1), 47-48. Retrieved from https://www.medicaljournals.se/jrm/.

Taggart, W. (1980). Human information processing styles and the information systems architect in the PSC systemeering model. Paper presented at the 17th Annual Computer Personnel Research Conference, Miami, FL. Retrieved from https:// dl.acm.org/citation.cfm?doid=800085.802732.

Taggart, W., \& Valenzi, E. (1990). Assessing rational and intuitive styles: A human information processing metaphor. Journal of Management Studies, 27(2) 149-172. Retrieved from https://ftp.the-intuitive-self.org/website/documents/ publications/rational intuitive.pdf.

Taggart, W.M., Valenzi, E., Zalka, L., \& Lowe, K.B. (1997). Rational and intuitive styles: Commensurability across respondent characteristics. Psychological Reports, 80(1), 23-33. Retrieved from https://libres.uncg.edu/ir/uncg/f/K_Lowe_Rational_1997.pdf.

UBS. (2016). Extreme automation and connectivity: The global, regional, and investmen implications of the fourth industrial revolution. UBS White Paper for the World Economic Forum Annual Meeting 2016. Retrieved from https://www.tadviser.ru/images/b/ b7/Extreme_automation_and_connectivity_The_global $\% 2 \mathrm{C}$ regional $\% 2 \mathrm{C}$ and investment implications_of the Fourth_Industrial_Revolution.pd.
Van Antwerpen, S. (2013). Key success factors influencing the productivity of administrative employees in the South African public sector. Unpublished Doctoral thesis, Tshwane University of Technology, Pretoria, South Africa.

Van Antwerpen, S., \& Ferreira, E. (2016). Contributing factors to poor service delivery by administrative employees in the Gauteng public service in South Africa. Africa Development, XLI(1), 81-98. Retrieved from https://www.ajol.info/index.php/ad/ article/viewFile/153826/143413.

Van Niekerk, T. (2007). Toepasbareaspekteuitbreinnavorsingsliteratuur op klavieronderrigvir beginners met spesifiekeverwysingna die heelbreinmodel van Ned Herrmann. Ongepubliseerdedoktoraleproefskrif.Pretoria, Suid-Afrika: Universiteit van Pretoria.

Venter, A.J. (2011). Thinking style preference profile of the contemporary administrative professional. Unpublished Master's dissertation, Tshwane University of Technology, Pretoria, South Africa.

World Economic Forum. (2016). The future of jobs: Employment, skills and workforce strategy for the fourth industrial revolution. Cologny, Switzerland: World Economic Forum. Retrieved from https://www3.weforum.org/docs/WEF Future_of_Jobs.pdf. 